\title{
A Hematological Study of the Walrus, Odobenus rosmarus
}

\author{
Elżbieta WOŁK \& Genadij M. KOSYGIN
}

Wołk E. \& Kosygin G.M., 1979: A hematological study of the walrus, Odobenus rosmarus. Acta theriol., 24, 9: 99-107 [With 2 Tables \& Figs.] In 62 walruses caught in the northwestern Chukchi Sea hemoglobin value $(\mathrm{Hb})$, number of erythrocytes $(R C B)$, diameter of erythrocytes ( $R B C$ diam.), mean corpuscular hemoglobin $(M C H)$, number of leukocytes $(W B C)$ and sedimentation rate of blood cells $(S R)$ were studied. In adult walruses these parameters are as follows: $\mathrm{Hb}-17.0 \pm 2.2$ $\mathrm{g} / 100 \mathrm{ml} ; R B C-2.89 \pm .9 \times 10^{6} / \mathrm{cmm} ; R B C$ diam. - 7.78 $2.6 \mu \mathrm{m} ; \mathrm{MCH}-$ $59.66 \pm 16.8 \mathrm{pg} ; W B C-6.244 \pm 266 / \mathrm{cmm} ; S R-4.8 \pm 2.2 \mathrm{~mm} / \mathrm{h}$. In the walrus hemoglobin concentration is higher than in pelagic Otaridae, yet it is lower than in Phocidae which are excellent divers. The $R B C$ count is lowest among the pinnipeds and is among the lowest value known for any mammal. Red blood cells are big and contain much hemoglobin. There is a positive correlation between the body weight of fetuses and pups and their hemoglobin concentration $(r=.797)$ and the $R B C$ value $(r=.958)$. In adult males a negative correlation between the body weight and hemoglobin concentration was observed $(r=$ -.577).

[Mammals Res. Inst., Polish Acad. Sci., 17-230 Białowieża, Poland, Inst. Biol. and Pedology, Far-Eastern Sci. Centre, USSR Acad. Sci, 690022 Vladivostok, USSR]

\section{INTRODUCTION}

Pinnipeds comprise a group of mammals extremely interesting for physiological studies in view of their aquatic life style and ability to dive. Thus they have been subjected to considerable hematological investigation as blood morphology and biochemistry can elucidate aspects of their adaptation to subaqueous activities. Basic blood parameters are known for over half of the species of the Order Pinnipedia (for review see L a ne et. al., 1972 and: $\mathrm{Kr}$ a ft, 1966; S ok olov, 1967, 1969; Ronald et al., 1969; Vally athan et al., 1969; Lenfant et al., 1970; $\mathrm{K}$ u s i n, 1972; G la zova, 1972, 1974). These species belong to two Families, Otaridae and Phocidae. The third Family Odobenidae, has been the least studied hematologically, though some data were given by Sokolov (1967) and Lenfant et al. (1970).

We therefore report hematologic parameters of walruses (Odobenus rosmarus Linnae us, 1758) taken in the northwestern part of the Chukchi Sea (part of the Arctic Ocean). 


\section{MATERIAL AND METHODS}

Blood from 62 walruses (14 adult males, 6 sexually immature males older than one year - »subadults «, one male pup, 35 adult females, 3 subadult females, and 3 female pups) was examined. The animals were shot from 20 June to 5 September 1973. Seven fetuses aged $2-3$ months were also examined.

Blood was taken during migration of walruses from their wintering sites to the summering areas and during their stay there. Pods consisting of only males were observed as well as of mixed sex and age congregations consisting of hundreds or thousands of individuals. Body weight and body length were

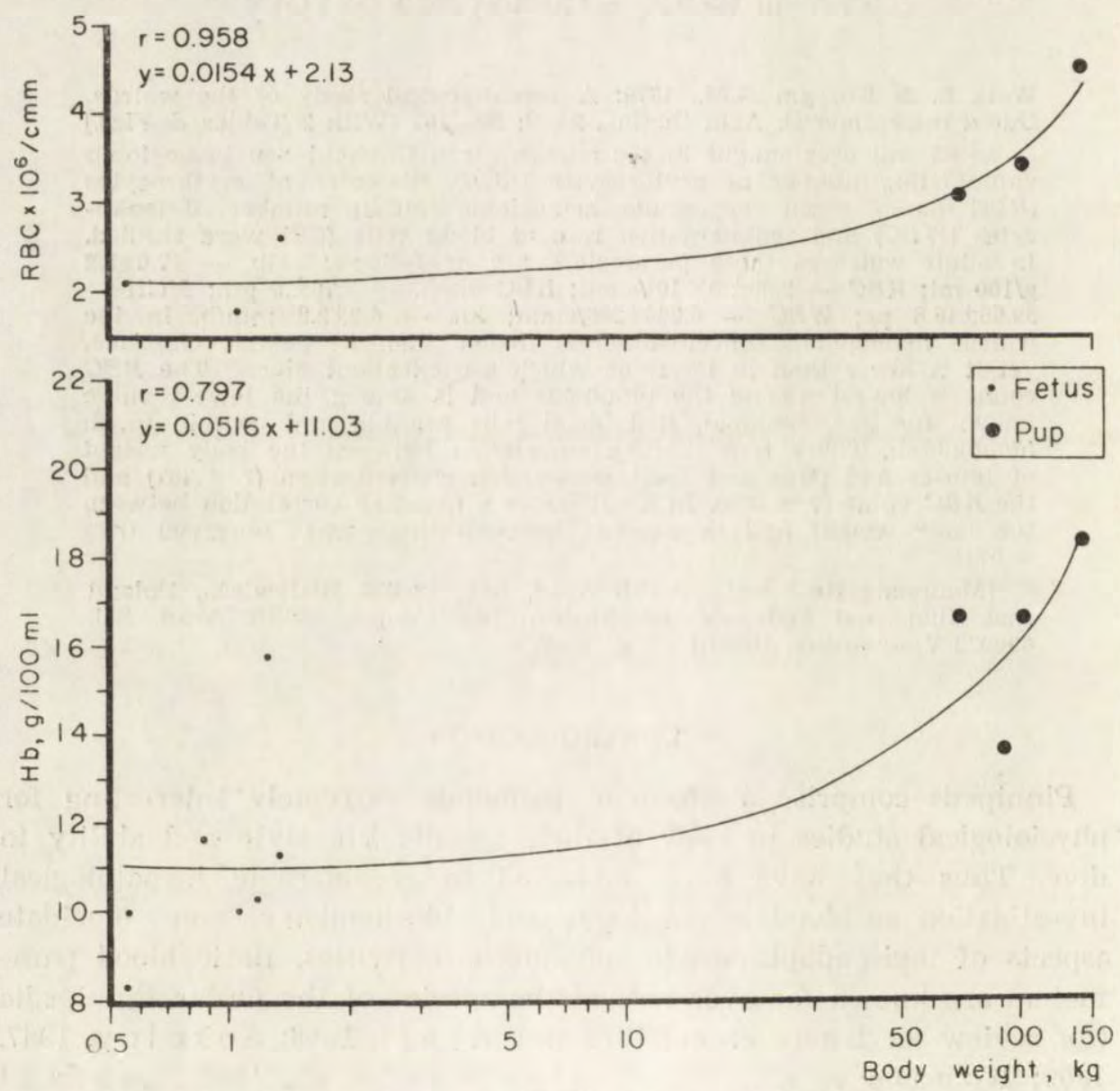

Fig. 1. Correlation between body weight, $\mathrm{Hb}$ values and $R B C$ parameters in young walruses,

determined for all walruses. Body length was measured along the back from tip of the nose to end of the tail. Blood was drawn from cranial vessels immediately after death (fetuses were removed from the uterus) using sodium citrate as an anticoagulum. Blood tests were performed immediately. Hemoglobin concentration $(\mathrm{Hb})$ was determined with a Sahli hemometer. Erythrocytes $(R B C)$ and leukocytes 
(WBC) were counted in a Bürker's chamber. Erythrocyte diameter (RBC diam.) was measured with a Zeiss ocular micrometer on smears stained by Pappenheim's method. Blood sedimentation rate $(S R)$ was defined by the micromethod. Mean corpuscular hemoglabin concentration $(\mathrm{MCH})$ was calculated.

\section{RESULTS}

No statistically significant differences in values of blood parameters among adult males and females were noted. Mean values were therefore

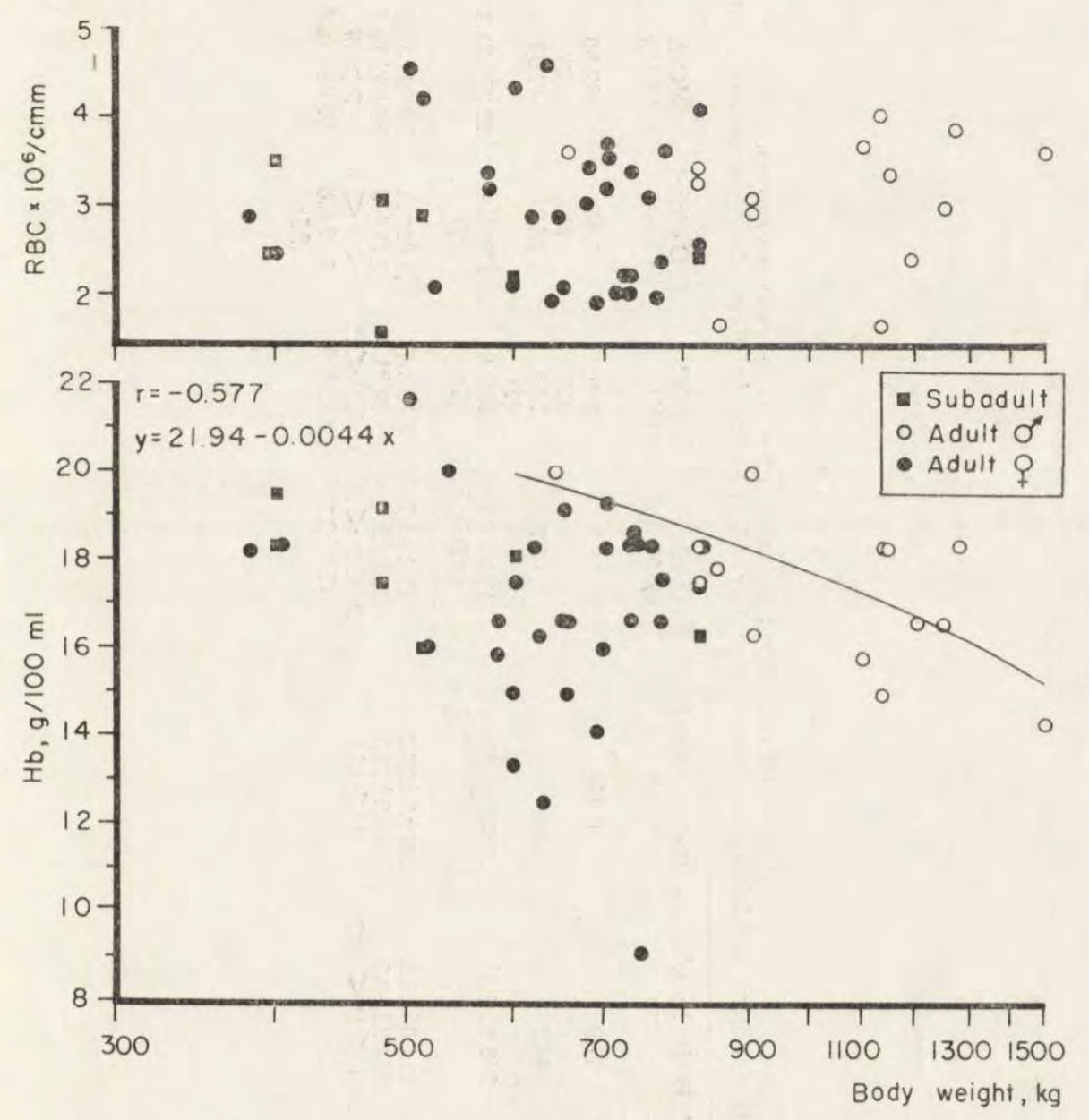

Fig. 2. Correlation between body weight, $\mathrm{Hb}$ values and $R B C$ parameters in subadult and adult walruses.

calculated from pooled adult data. Due to the small number of individuals in other age groups, the sexes were also treated jointly (Table 1). 
102

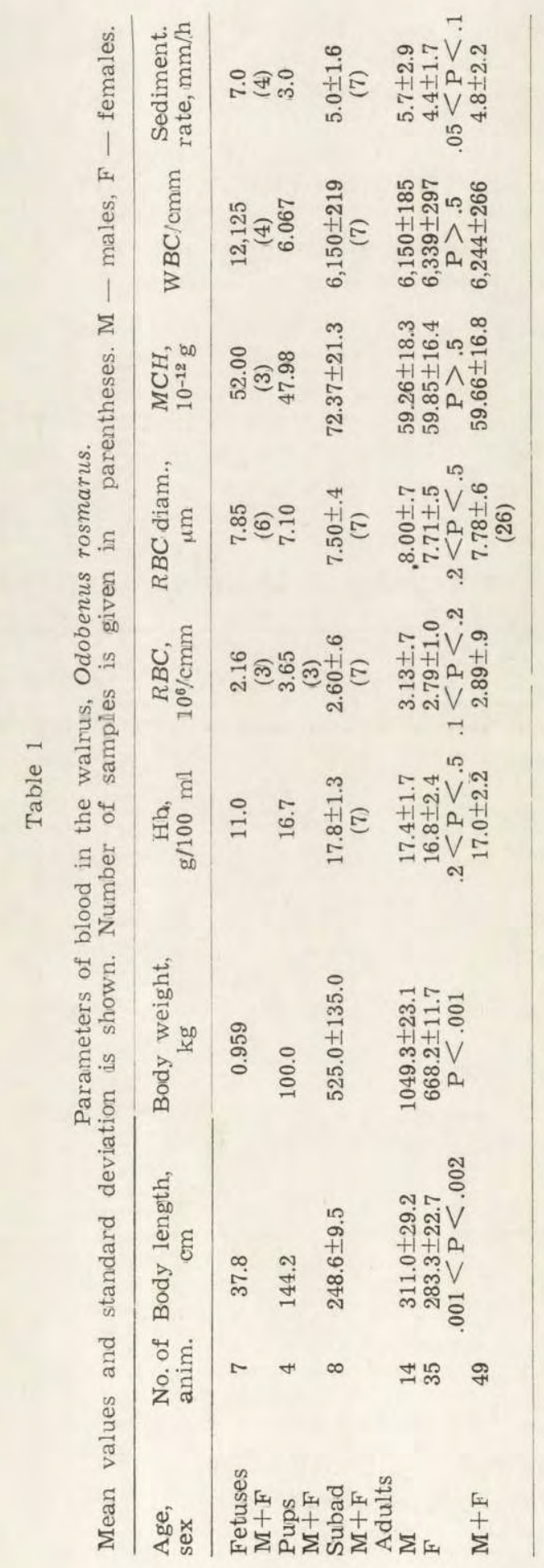


During the growth of walruses a rise in those blood parameters affecting respiratory functions was observed. Hemoglobin concentration rises from $11.0 \mathrm{~g} / 100 \mathrm{ml}$ in fetuses to 17.0 in adults $(P<.001$; Table 1$)$. There is also a correlation between the body weight and $\mathrm{Hb}$ value in fetuses and pups $(r=.797 ; .001<P<.01 ;$ Fig. 1$)$. This relation is different in adults. In males there is a negative correlation between the body weight and $\mathrm{Hb}(r=-.577 ; .5<P<.02)$. In female adults there is no correlation (Fig. 2).

In four cases there is possible a comparison of $\mathrm{Hb}$ value in a pregnant female and its fetus. In three of these cases a definite relation between these parameters was observed i.e. the higher value in a female resulted in a higher value in the fetus (Table 2).

Table 2

A comparison of blood parameters of pregnant females Odobenus rosmarus and their fetuses. $M$ - male, $F$ - female, $f$ - fetus.

\begin{tabular}{|c|c|c|c|c|c|c|c|}
\hline & $\begin{array}{c}\text { Body } \\
\text { length, } \mathrm{cm}\end{array}$ & $\begin{array}{c}\text { Body } \\
\text { weight } \mathrm{kg}\end{array}$ & $\begin{array}{c}\mathrm{Hb}, \\
\mathrm{g} / 100 \mathrm{ml}\end{array}$ & $\begin{array}{c}\mathrm{RBC} \\
10^{6} / \mathrm{cmm}\end{array}$ & $\begin{array}{l}M C H, \\
10^{-12} \mathrm{~g}\end{array}$ & WBC/omm & $\begin{array}{l}\text { Sediment. } \\
\text { rate, } \mathrm{mm} / \mathrm{h}\end{array}$ \\
\hline $\mathrm{F}^{1}$ & 270.0 & 740.00 & 18.6 & 3.36 & 55.36 & 6,200 & 6 \\
\hline $\mathrm{Ff}^{1}$ & 36.0 & 1.25 & 15.8 & 2.61 & 60.34 & 7,200 & - \\
\hline $\mathrm{F}^{2}$ & 300.0 & 740.00 & 18.3 & 2.24 & 81.70 & 9,150 & 8 \\
\hline Mf $^{2}$ & 28.0 & 0.55 & 10.0 & - & - & - & - \\
\hline $\mathrm{Mf}^{3}$ & 30.0 & 1.05 & 10.0 & 1.80 & 55.55 & 12,500 & 8 \\
\hline $\mathrm{Mf}^{3}$ & 30.5 & 1.15 & 10.3 & - & - & 13,400 & 12 \\
\hline$F^{4}$ & 285.0 & 600.00 & 15.0 & 2.08 & 72.11 & 14,500 & - \\
\hline $\mathrm{Ff}^{4}$ & 33.0 & 0.86 & 11.6 & - & - & - & 5 \\
\hline$F^{4}$ & 268.0 & 640.00 & 13.3 & 4.57 & 29.10 & 4,900 & 3 \\
\hline $\mathrm{Mf}^{4}$ & 40.0 & 1.30 & 11.3 & - & - & - & 3 \\
\hline$M f^{4}$ & 25.0 & 0.55 & 8.3 & 2.08 & 39.90 & 15,400 & - \\
\hline
\end{tabular}

Date caught: ${ }^{1}$ Aug. $24,{ }^{2}$ Aug. 26, ${ }^{3}$ Sept. 4 , ${ }^{4}$ Sept. 5.

$R B C$ count of fetuses and pups was correlated with body weight $(r=.958 ; .001<P<.01 ;$ Fig. 1$)$. Yet in subadult and adult specimens no correlation between $R B C$ and body weight was found (Fig. 2). There also is no mutual relationship between body size of walruses and $\mathrm{MCH}$ and $S R$. Thus increased $\mathrm{Hb}$ and $R B C$ value seen closely corresponds to age, since body weight is age-related in walruses (Krylov, 1970). Fetal $W B C$ value is twice that of neonates. This value does not change further during the animal's life (Table 1). The mean blood sedimentation rate of adults was $4.41 \mathrm{~mm} / \mathrm{h}$, the maximum rising above $10 \mathrm{~mm} / \mathrm{h}$ in only one individual $(13 \mathrm{~mm} / \mathrm{h})$. Therefore it was assumed after So k o$10 \mathrm{v}(1967)$ that those values accurately reflected the normal physiological condition of adult walruses. 


\section{DISCUSSION}

Elevation of blood parameters during the growth of the walrus is probably consequent upon a change in the way of the life of the young unimal, i.e. adaptation to swimming and getting food from the sea bottom which in turn, demands increased oxygen availability while diving. According to $\mathrm{Ny} \mathrm{holm} \mathrm{(1975)} \mathrm{the} \mathrm{average} \mathrm{walrus} \mathrm{dive} \mathrm{duration}$ was $4.8 \mathrm{~min}$. P e r r y (1976) cited dive depths to $90 \mathrm{~m}$ lasting $8-10 \mathrm{~min}$. In many other species of pinnipeds the period spent under water is much longer ( $\mathrm{K}$ o o y $\mathrm{ma} \mathrm{n,} \mathrm{1966).} \mathrm{A} \mathrm{distinct} \mathrm{rise} \mathrm{in} \mathrm{hemoglobin} \mathrm{concen-}$ tration, $R B C$ number, $M C H, M C H C, M C V$ values and the blood volume is observed during the postnatal development of expertly diving species (Bryden \& Lim, 1969; Geraci, 1971; Lane et al., 1972). Most species of pinnipeds have higher $\mathrm{Hb}$ concentration than does the walrus. According to our data mean value is $17.0 \mathrm{~g} / 100 \mathrm{ml}$; Sokolov (1967) states $14.0-17.0$ and L e $\mathrm{f}$ a n t et al. (1970) cite $16.7 \mathrm{~g} / 100 \mathrm{ml}$ in adult walruses. Pinnipeds exhibit a higher basic metabolisms (I rving \& $\mathrm{H}$ a r t, 1957) but unfortunately no data exist concerning walrus metabolic rate. It may be supposed that $\mathrm{Hb}$ values and metabolic rates are related. Walruses are lethargic, resting ashore or on ice, even migrating by riding ice-floes over long distances. They eat torpid shallow water Mollusca and Crustacea (C hapski j, 1936; N i kulin, 1941; K r y lov, 1971). Walruses do not swim very fast compared with carnivorous pinnipeds. In Weddell seals (Leptonychotes weddelli) and harp seals (Pagophilus groenlandicus) which cover large distances very quickly, $\mathrm{Hb}$ concentrations are as high as $20 \mathrm{~g} / 100 \mathrm{ml}(\mathrm{P} u \mathrm{~g} \mathrm{~h}, 1959$; R o nald et al., 1969; V a 11 y a th a $\mathrm{n}$ et al., 1969; G e r a ci, 1971). Values lower than in walruses characterize the Otaridae (Lenfant \& $\mathrm{Hubbard}$, 1967; L e $\mathrm{f}$ a $\mathrm{n}$ t et al., 1969, 1970; $\mathrm{K}$ u z in, 1972).

$R B C$ counts of walruses is minimal among the Pinnipedia ( $\mathrm{S}$ o k o lo v, 1967; Lenfant et al., 1970; present study). Generally all pinnipeds have low $R B C$ values. Maximal $R B C$ count occurs in the Family Phocidae ( $5 \mathrm{mill} / \mathrm{mm}^{3}$ ) (L e n f a n t \& H u b b a r d, 1967; Ronald et al., 1969; Lenfant et al., 1970; Geraci, 1971; Greenwood et al., 1971; Glazova, 1974). It is therefore possible to suppose that the subdivision of Pinnipedia into Phocidae which are excellent divers, and the pelagic Otaridae and Odobenidae finds its reflection in $R B C$ number and $\mathrm{Hb}$ concentration. Odobenidae and Otaridae are morphologically related also (S c h e f f e r, 1958).

The relatively great $R B C$ diameter of pinnipeds is inversely correlated with low $R B C$ number, as in other mammals. Tyler (1960) gives $9.0 \mu \mathrm{m}$ for crabeater seal (Lobodon carcinophagus) $R B C$ diameter and Lane et al. (1972) cites $10.06 \mu \mathrm{m}$ for the southern elephant seal 
(Mirounga leonina). The fact that the $R B C$ diameter of 6 fetuses is almost identical to that of adult walruses $(7.85 \mu \mathrm{m}$ vs $7.78 \mu \mathrm{m})$ is very interesting. In pups and subadults this value is slightly lower than in adults (Table 1) yet this may result from the small number studied. $R B C$ diameter in the walrus seems constant, contrary to the condition in many smaller mammals (e.g. Soricinae; Wo $\mathrm{lk}, 1974$ ) in which $R B C$ diameter decreases drastically during postnatal life. This fact may be interpred in many ways. Szarski (1974) however hypothesized that the occurence of larger erythrocytes in mammal embryos is a sing of the evolutional past of these animals. In small mammals characterized by a high level of metabolism the phylogenetic decrease of erythrocyte size resulted in a greater blood efficiency. In big and torpid walruses there migth be no such physiologic necessity and erythrocyte diameter remained unchanged.

It should be stressed that no significant differences exist between the blood indices of males and females, males having only slightly higher values (Table 1) even though sexual dimorphism is very distinct in walruses. Body length and especially the body weight are much greater in males $(.001<P<.002 ; P<.001$ respectively). In northern fur seals (Callorhinus ursinus) $\mathrm{Hb}$ concentration and $R B C$ number is nearly $10 \%$ greater in males than in females ( $\mathrm{K} \mathrm{u} \mathrm{z} \mathrm{in,} \mathrm{1972).} \mathrm{Yet} \mathrm{these}$ differences are statistically insignificant too.

The inverse relation between body weight and $\mathrm{Hb}$ value of adult males (Fig. 2) seems ironic. Dominant males are characterized by great body weight (Mille r, 1975) but dominants are also very placid during provocation and fight rarely. Most probably their activity is even less that of subordinate males. Their domination does not depend upon a greater metabolic rate.

Generally walrus blood morphology is characterized, by features common to the blood of all pinnipeds, i.e., high $\mathrm{Hb}$ concentration, a relatively small number of $R B C \mathrm{~s}$ of great diameter and volume, thus with a high $M C H$ value (Lenfant, 1969). Higher $M C H$ occur only in the Weddell seal ( $\mathrm{Pugh}, 1959)$, in the norhern elephant seal (Mirounga angustirostris) (Lenfant \& $\mathrm{Hubbard}, 1967$ ) and in the southern elephant seal ( $\mathrm{L}$ an e et al., 1972). These characteristics indicate large blood oxygen reserves of pinnipeds, presumably reflecting their diving habits.

Acknowledgments: We thank Mrs. Z.K. Larceva (University of Irkutsk) for technical help, Dr A.S. Sokolov (Zoological Institute Acad. of Sci., Leningrad) for his kind help in preparing the manuscript and Dr. G.L. Dryden (USA) for reading the paper. 


\section{REFERENCES}

1. Bryden M. M. \& Lim G. H. K., 1969: Blood parameters of the southern elephant seal (Mirounga leonina, Linn.) in relation to diving. Comp. Biochem. Physiol., 28: 139-148.

2. Chapskij K. K., 1936: Morž Karskogo morja. Tr. Arkt. Inst., 27: 9-111. Leningrad.

3. Geraci J. R., 1971: Functional hematology of the harp seal Pagophilus groenlandicus. Physiol. Zoöl. 44: 162-170.

4. Gla zova T. N., 1972: Fiziologo-biochimičeckaja charakteristika krovi detenyšej grenlandskogo tjulenja Pagophilus groenlandicus. V Vses. sov. izuč. morskich mlekopitajuščich, 2: 63-65. Machačkala.

5. Glazova T. N., 1974: Adaptacija krovi i krovetvornych organov mlekopitajuščich $\mathrm{k}$ vodnomu obrazu žizni. Ist Inter. Theriol. Congress, 1: 194-195. Moskva.

6. Greenwood A. G., Ridgway S. H. \& Harrison R. J., 1971: Blood values in young gray seals. J. Am. vet. med. Ass., 159: 571-574.

7. Irving L. \& Hart J. S., 1957: The metabolism and insulation of seals as bare-skinned mammals in cold water. Can. J. Zool., 35: 497-511.

8. Kooyman G. L., 1966: Maximum diving capacities of the Weddell seal, Leptonychotes weddelli. Science, 151: 1553-1554.

9. $\mathrm{Kr}$ aft $\mathrm{H}$. von, 1966: Das morphologische Blutbild vom europäischen Seehund (Phoca vitulina L.). Blut, 14: 169-171.

10. Krylov V. I., 1970: Razmerno-vesovaja charakteristika kak pokazatel vozrastno-polovogo dimorfizma u tichookeanskogo morža. Bull. Mosk. Obšč. Isp. Prirody, 5: $18-24$.

11. Krylov V. I., 1971: O pitanii tichookeanskogo morža (Odobenus rosmarus divergens I11.). Tr. Atlant. Naučno-issled. Inst. Rybn. Choz. Okeanogr., 39: $110-116$.

12. Kuzin A. E., 1972: Ekologo-fiziologičeskie i vozrastnye osobennosti krasnoj krovi morskich kotikov (Callorhinus ursinus L.). Teriologija, 1: $312-318$.

13. L a ne R. A. B., Morris R. J. H. \& Sheedy J. W., 1972: A haematological study of the southern elephant seal, Mirounga leonina (Linn.). Comp. Biochem. Physiol., 42 (4A): $841-850$.

14. Lenfant C., 1969: Physiological properties of blood of marine mammals. [In: "The Biology of Marine Mammals«, ed. H. T. Anderson], Academic Press: 95-116. New York, London.

15. Lenfant C. \& Hubbard R. C., 1967: Unpublished abservations eited in Lenfant (1969).

16. Lenfant C., Elsner R., Kooyman G. L. \& Drabek C. M., 1969: Respiratory function of blood of the adult and fetus Weddell seal Leptonychotes weddelli. Am. J. Physiol., 216: 1595-1597.

17. Lenfant C., Johansen K. \& Torrance J. D., 1970: Gas transport and oxygen storage capacity in some pinnipeds and the sea otter. Resp. Physiol., 9: $277-286$.

18. Mille r E. H., 1975: Walrus ethology. I. The social role of tusks and applications of multidimensional scaling. Can. J. Zool., 53: 590-613.

19 Nikulin P. G., 1941: Cukotskij morž. Izv. Tichookean. Naučno-issled. Inst. Rybn. Choz. Okeanogr. 20: 21-59. Vladivostok.

20. Nyholm E. S., 1975: Observations on the walrus (Odobenus rosmarus L.) in Spitsbergen in 1971-1972. Ann. Zool. Fennici, 12: 193-196. 
21. Perry R., 1976: Mir morža [The World of the Walrus]. Gidrometeoizdat: 1-94. Leningrad,

22. Pugh L. G. C. E., 1959: Carbon monoxide content of the blood and other observations on Weddell seals. Nature, 183: 74-76.

23. Ronald K., Foster M. E. \& Johns on E., 1969: The harp seal, Pagophilus groenlandicus (Erxleben, 1777). II. Physical properties. Can. J. Zool., 47: 461-468 .

24. Scheffer V. B., 1958: Seals, Sea Lions and Walruses. Stanford-London: 3-179 .

25. Sok olov A. S., 1967: Opyt issledovanija osobennostej knovi severotichookeanskich lastonogich. Izv. Tichookean. Naučnoissled. Inst. Rybn. Choz. Okeanogr., 21: 137-146. Vladivostok.

26. Sokolov A. S., 1969: Količestvo mioglobina i krovi u nekotorych ušastych i nastojaščich tjuleniej. IV Vses. sov. izuč. morskich mlekopitajuščich, 193-196. Kaliningrad.

27. Szarski H., 1974: Zagadnienie rozmiarów komórek zwierząt kręgowych. Postępy biologii komórki, 1: $311-344$.

28. Tyler J. C., 1960: Erythrocytes and hemoglobin in the crabeater seal. J. Mammal., 41: 527.

29. Vallyathan N. V., George J. C. \& Ronald K., 1969: The harp seal, Pagophilus groenlandicus (Erxleben, 1777). V. Levels of haemoglobin, iron, certain metabolites and enzymes in the blood. Can. J. Zool., 47: 1139-1197.

30. Wolk E., 1974: Variations in the hematological parameters of shrews. Acta theriol., 19: $315-346$.

Accepted, September 8, 1978.

Elżbieta WOŁK i Genadij M. KOSYGIN

HEMATOLOGIA MORSA, ODOBENUS ROSMARUS

\section{Streszczenie}

U 62 morsów schwytanych w NW części Morza Czukockiego badano poziom hemoglobiny $(\mathrm{Hb})$, liczbę erytrocytów $(R C B)$, średnicę erytrocytów (RBC diam.), ilość hemoglobiny w krwince $(M C H)$, liczbę leukocytów (WBC), szybkość opadania krwinek (SR). U dorosłych morsów parametry krwi są następujące: $\mathrm{Hb}-17.0 \pm 2.2$ $\mathrm{g} / 100 \mathrm{ml} ; R B C-2.89 \pm .9 \times 10^{6} / \mathrm{mm}^{3} ; R B C$ diam. $-7.78 \pm .6 \mu \mathrm{m} ; M C H-59.66 \pm 16.8 \mathrm{pg}$; $W B C-6244 \pm 266 / \mathrm{mm}^{3} ; S R-4.8 \pm 2.2 \mathrm{~mm} / \mathrm{h}$ (Tabela 1). Poziom hemoglobiny jest więc $u$ morsa wyższy niż u pelagicznych Otaridae, niższy natomiast niż u znakomicie nurkujących Phocidae. Liczba $R B C$ jest najniższa wśród płetwonogich i należy w ogóle do najniższych wśród ssaków. Czerwone krwinki są duże i bogate w hemoglobinę. Istnieje dodatnia korelacja między ciężarem ciała embrionów i osesków a ilością hemoglobiny $(n=.797)$ oraz wartością $R B C(\mathrm{r}=.958)$ (Rys. 1). U dorosłych samców wykazano ujemną korelację między ciężarem ciała a ilością hemoglobiny ( $r=-.577$ ) (Rys. 2). 